\title{
PENINGKATAN PEMAHAMAN DAN PENGIMPLEMENTASIAN WISATA ISLAMI BAGI PELAKU WISATA DI KOTA PADANG
}

\author{
Yunia Wardi ${ }^{1}$, Abror $^{2}$, Okki Trinanda ${ }^{3}$
}

\begin{abstract}
Abstrak
Islamic tourism is considered to have a very good prospect in the development of tourism in Indonesia, especially in the city of Padang. This assessment came about because of the culture of the people in the Islamic city of Padang. But despite the huge potential, there are still some problems related to the service. Whereas the implementation of good Islamic tourism is with the integration of various aspects of tourism services that exist. That is starting from the promotion of tourism, tourism service itself until the tourists are back again to their respective regions. Based on the background of the importance of Islamic tourism services in the tourist areas above, the activities of community service in the form of Islamic tourism service training is implemented, to provide insight into aspects of excellent service to tourists who make the tourist area more attractive and satisfying. As for the object of community service activities is the actors of tourism that deal directly with the tourists who come to the city of Padang. Namely the managers of travel bureaus, hotels, guides, guides, taxi drivers, and other parties. With the implementation of this activity, tourism actors have a good understanding of the concept and importance of Islamic Tourism, so they can integrate various tourist services to create a good Islamic tourism experience for tourists.
\end{abstract}

\author{
Kata-kata Kunci: \\ Islamic Tourism, \\ marketing Integration
}

\section{Pendahuluan}

Wisata Islam merupakan sebuah tren yang sedang berkembang pesat di dunia pariwisata saat ini. Hal ini terbukti dengan semakin maraknya destinasi wisata yang menyatakan diri sebagai kawasan wisata Islami ataupun wisata halal, baik di dalam negeri maupun internasional. Perkembangan ini didorong dengan semakin tumbuhnya jumlah wisatawan muslim dari tahun ke tahun. Tercatat pertumbuhan wisata Islami rata-rata $6 \%$ lebih cepat dari subsektor pariwisata lainnya. Wisatawan muslim di dunia mencapai USD145 miliar dari sekitar 108 juta orang. Hingga 2020, jumlah wisatawan muslim diperkirakan mencapai 150 juta orang (Kemenpar, 2016).

Wisata Islam dinilai memiliki prospek yang sangat bagus dalam perkembangan pariwisata di Indonesia, terutama di Kota Padang. Penilaian ini muncul karena budaya masyarakat di Kota Padang yang Islami. Kota Padang yang adat istiadatnya sangat kental dengan nuansa Islam, terutama dengan dasar budayanya yaitu "adat basandi syara', syara' basandi kitabullah" atau adat berdasarkan agama dan agama berdasarkan Al-Quran. Sehingga kehidupan bermasyarakat di Kota Padang berjalan sebagaimana aturan syariah, mulai dari kuliner halal, etika pergaulan, pakaian dan seterusnya.

Potensi pasar pariwisata halal makin prospektif karena jumlah pendapatan yang didapatkan dari wisatawan muslim terbilang tinggi. Rata-rata kaum muslim yang ada di Asia, Amerika, dan Eropa merupakan kalangan kelas menengah. Kementerian Ekonomi Kreatif (Kemenparekraf) menjadikan Indonesia sebagai salah satu destinasi wisata halal di dunia. Tiga provinsi di Indonesia telah ditetapkan sebagai destinasi wisata halal yaitu, Aceh, Nusa Tenggara Barat (NTB) dan Kota Padang telah ditetapkan pemerintah sebagai destinasi wisata halal di Indonesia.

Namun dibalik potensi yang besar tersebut, masih terdapat beberapa permasalahan yang terkait dengan pelayanan. Padahal penyelenggaraan wisata Islam yang baik adalah dengan adanya pengintegrasian berbagai aspek pelayanan wisata yang ada. Yaitu mulai dari promosi wisata, pelayanan wisata itu sendiri hingga wisatawan tersebut kembali lagi ke daerahnya masing-masing.

Dalam hal promosi wisata, konten promosi yang disusun tentunya menonjolkan sisi Islami dari dunia pariwisata Kota Padang. Mulai dari ketersediaan kulinernya yang lezat dan halal, budaya masyarakatnya yang Islami, hingga destinasi-destinasi wisata Islami yang terkenal, seperti Mesjid, wisata ziarah dan seterusnya. Dalam hal mempromosikan wisata, tentu tidak terbatas pada promosi melalui media sosial dan media massa semata, namun juga pada saat wisatawan telah datang ke Kota Padang. Hal

\footnotetext{
* Corresponding author.

E-mail Addresses: yuniawardi@gmailcom (Yunia Wardi), 2abror094@gmail.com (Abror) 3okki.miaz@gmail.com (Okki Trinanda)
} 
ini dimulai dari kemampuan supir taksi atau pramuwisata menjelaskan berbagai pilihan destinasi wisata, hingga ketersediaan brosur serta perlengkapan lainnya.

Pada saat wisatawan datang berkunjung, diperlukan berbagai pelayanan prima sehingga wisatawan dapat terpuaskan. Mulai dari fasilitas pendukung seperti ketersediaan tempat ibadah yang bersih, penunjuk kiblat di kamar-kamar penginapan hingga fasilitas wisata itu sendiri. Berbagai fasilitas dan aspek pelayanan tersebut saling terintegrasi dengan baik, hingga pelayanan wisata Islam merupakan sebuah pengalaman komprehensif yang diterima oleh wisatawan.

Berdasarkan latar belakang akan pentingnya pelayanan wisata Islam pada kawasan-kawasan wisata di atas, maka kegiatan pengabdian kepada masayarakat berupa pelatihan pelayanan wisata Islam ini perlu untuk dilaksanakan, untuk memberikan wawasan mengenai aspek-aspek pelayanan prima kepada wisatawan Islam yang membuat kawasan wisata menjadi lebih menarik dan memuaskan.

Adapun yang menjadi objek kegiatan pengabdian kepada masyarakat ini adalah para pelaku wisata yang berhubungan langsung dengan para wisatawan yang datang ke Kota Padang. Yaitu para pengelola travel biro, hotel, pramuwisata, guide, supir taksi, serta pihak-pihak lainnya.

Dengan dilaksanakannya kegiatan ini, diharapkan para pelaku wisata tersebut memiliki pemahaman yang baik akan konsep serta pentingnya Wisata Islami, sehingga mereka dapat mengintegrasikan berbagai layanan wisata untuk menciptakan pengalaman wisata Islami yang baik bagi para wisatawan.

\section{Metode}

Secara umum metode penerapan yang akan digunakan adalah kegiatan sosialisasi dan pelatihan wisata Islam pada para pelaku wisata di Kota Padang. Secara khusus, metode kegiatan sosialisasi yang akan dilakukan adalah: 1) Ceramah. Untuk meningkatkan pengetahuan tentang pentingnya pelayanan wisata dan pelayanan wisata Islam. Kegiatan ini akan dibantu dengan media power point, 2) Diskusi Kelompok. Metode ini digunakan untuk meningkatkan kemampuan dalam menciptakan pelayanan wisata Islam. Kegiatan ini akan dilakukan di bawah panduan instruktur, 3) Kuis. Metode ini akan digunakan untuk meningkatkan pengetahuan pentingnya pelayanan wisata Islam.

\section{Hasil dan Pembahasan}

Kegiatan Pengabdiuan Kepada Masyarakat dengan judul "Pelatihan Wisata Islami Kepada Pelaku Wisata Kota Padang" dilaksanakan pada hari Kamis 28 September 2017 di Gedung Bung Hatta pada Lembaga Penjaminan Mutu Pendidikan Sumatera Barat. Kegiatan ini diikuti oleh para pelaku wisata dari berbagai kalangan, dan dengan menghadirkan para narasumber yang berkompeten baik dari pemerintahan maupun dari perguruan tinggi.

Persiapan kegiatan dilaksanakan dengan melakukan kajian pustaka terhadap ilmu-ilmu terbaru terkait dengan Wisata Islami. Dengan adanya kajian pustaka ini, para pelaku kegiatan memiliki dasar dalam menyusun angket yang akan disebarkan kepada para pelaku wisata di Kota Padang, sekaligus juga menjadi dasar dalam menentukan siapa audiens yang akan diundang.

Adapun para peserta yang menjadi audiens dari kegiatan ini adalah para pelaku wisata yaitu pelaku perhotelan, transportasi, tour guide, biro wisata, dan lain sebagainya. Para pelaku wisata tersebut diundang dengan tujuan untuk memberikan pemahaman sehubungan dengan wisata Islami, serta mengintegrasikan pelayanan wisata Islami yang saling terkait.

Berdasarkan hasil kajian serta diskusi, maka Narasumber pada acara Pelatihan ini adalah: 1) Drs. Didit P. Santoso, M.Si. (Kabid Pemasaran Dinas Pariwisata Sumbar), 2) Dr. Yuliana, SP., M.Si (Dosen Pariwisata, Fakultas Pariwisata dan Perhotelan UNP, 3) Dr. Susi Evanita, MS (Dosen Komunikasi Pemasaran, Fakultas Ekonomi UNP).

Persiapan selanjutnya dari acara ini adalah persiapan tempat. Pada proposal, kegiatan ini direncanakan dilaksanakan di Fakultas Ekonomi UNP. Namun dikarenakan adanya bentrok jadwal dengan agenda Fakultas pada ruangan yang sama, maka kegiatan ini pada akhirnya dilaksanakan di Gedung Bung Hatta pada Lembaga Penjaminan Mutu Pendidikan Sumatera Barat.

Pembagian undangan dan pengurusan ijin kegiatan, dilaksanakan satu minggu sebelum kegiatan dilaksanakan. Pada tahapan kegiatan ini, para pelaku pengabdian tidak mengalami kendala apapun. Bagi peserta yang telah diundang, panitia melakukan konfirmasi kehadiran satu hari sebelum acara dilaksanakan. Hal ini dikarenakan kuota peserta yang ditetapkan sebanyak 30 orang, sehingga apabila ada peserta yang berhalangan hadir, maka panitia langsung menyebarkan undangan kepada peserta baru. Strategi ini terbukti efektif, karena pada saat acara dilaksanakan jumlah peserta pas sebanyak 30 orang. 
Penyusunan angket juga dilaksanakan oleh tim pengabdian kepada masyarakat selama satu minggu sebelum kegiatan dilaksanakan. Pada angket, pertanyaan dan pernyataan yang diajukan terkait dengan informasi responden, bidang yang mereka tekuni, pernyataan-pernyataan spesifik sesuai dengan bidang masing-masing, serta pertanyaan terbuka sehingga responden dapat memberikan masukan kepada tim pengabdian kepada masyarakat.

Kegiatan Pelatihan Wisata Islami Kepada Para Pelaku Wisata Islami dimulai pada jam 08.00 WIB. Acara diawali dengan pembacaan ayat suci Al Quran dan dibuka resmi oleh Ketua Kegiatan Prof. Dr. Yunia Wardi. Drs., M.Si. Pada pembukaan, prof. Dr. Yunia Wardi, Drs., M.Si mengemukakan perlunya para pelaku wisata di Kota Padang untuk mengikuti tren pariwisata terkini, terutama setelah Kota Padang mendapatkan penghargaan sebagai destinasi wisata halal terbaik dunia. Hal tersebut yang kemudian menjadi salah satu latar belakang dilaksanakannya kegiatan pengabdian ini.

Adapun Narasumber pertama, yaitu Drs. Didit P Santoso, M.Si, Kasubdit Pemasaran Dinas Pariwisata Provinsi Sumatera Barat menyampaikan materi yang berjudul "Halal Friendly Travel". Narasumber membuka pemaparannya dengan berbagai fakta dan statistik terkini sehubungan dengan Pariwisata, serta berbagai ketentuan dan kebijakan dari pemerintah.

Narasumber menjelaskan bahwa penerapan wisata Islami di Kota padang merupakan strategi yang dapat memperluas segmentasi pasar, tanpa kehilangan pelanggan yang telah ada. Sehingga para pelaku wisata tidak akan mengalami kerugian apa-apa, bahkan bisa mendapatkan keuntungan.

Pada kesempatan tersebut Narasumber juga menyampaikan besarnya potensi dari wisata Islami karena yang menjadi peminat wisata ini tidak terbatas kepada muslim saja. Berbagai destinasi Islai/ halal di seluruh dunia juga telah terbukti menjadi incaran para wisatawan non muslim. Hal ini karena aspek kebersihan, keamanan, ketertiban dan transaksi pada kawasan wisata Islami lebih terjamin.

Adapun kebutuhan-kebutuhan yang harus dipenuhi pada wisata Islami adalah; 1) Makanan halal, 2) Fasilitas beribadah, 3) Pelayanan Ramadhan, 4) Ketersediaan toilet yang bersih, 5) Larangan terhadap kegiatan non halal, 6) Fasilitas rekreasi, dan 7) Pelayanan-pelayanan privasi.

Selanjutnya Narasumber kedua, Dr. Susi Evanita, MS menyampaikan materi dengan judul "Strategi Pemasaran Wisata Islami". Narasumber kedua memberikan pmaparan mengenai berbagai potensi wisata yang telah ada di Sumatera Barat. Berbagai destinasi dengan keindahan alam, serta kekayaan kuliner menjadi aset utama dalam menjalankan wisata Islami. Namun hal tersebut belum dapat dipasarkan dengan baik tanpa adanya konsep pemasaran yang mengutamakan kepuasan pelanggan (wisatawan).

Narasumber menjelaskan Tiga Unsur Konsep Pemasaran, yaitu; 1) Orientasi pada konsumen, 2) Penyusunan Kegiatan Pemasaran Secara Integral, 3) Kepuasan Konsumen

Narasumber menjelaskan bahwa ketiga hal inilah yang menjadi kelemahan pariwisata selama ini, dimana aset wisata yang telah dimiliki selama ini tidak disampaikan dengan pelayanan yang baik. Padahal jika kedua hal tersebut disatukan, maka pariwisata Sumatera Barat dipastikan akan mengalami kemajuan yang pesat.

Pada sesi ini juga ditekankan peranan media sosial, dimana setiap kejadian, kepuasan, ketidakpuasan wisatawan akan cepat sekali menyebar dan menimbulkan word of mouth. Bagi wisata Islami Kota Padang, tentu word of mout yang diinginkan adalah yang bernada positif.

Selanjutnya Narasumber ketiga yaitu Dr. Yuliana, SP., M.Si memaparkan materi yang berjudul "Pelayanan Wisata Islami Berorientasi Pelanggan". Pada sesi ini Narasumber menjelaskan konsep wisata Islami dan wisata Halal, baik dalam persepktif keilmuan, peraturan maupun dalam agama Islam sendiri.

Narasumber juga menjelaskan berbagai kebutuhan wisatawan, yaitu: 1) Kebutuhan informasi, 2) Kebutuhan transportasi, 3) Kebutuhan makan dan minum, 4) Kebutuhan melihat sesuatu yang unik dan indah, 5) Kebutuhan beristirahat, santai, relaks, bersenang-senang, berolahraga, bercengkrama 6) Kebutuhan berbelanja, baik untuk memenuhi kebutuhan maupun oleh-oleh, dan 7) Kebutuhan untuk dokumentasi sebagai kenang-kenangan.

Berbagai kebutuhan tersebut diatas adalah peluang-peluang yang harus ditangkap oleh para pelaku wisata di Kota Padang. Senada dengan Narasumber sebelumnya, Narasumber ketiga juga memaparkan kelemahan pelayanan oleh para pelaku wisata di Sumatera Barat. Sehingga berbagai potensi wisata yang sebenarnya sangat kaya belum dapat dipasarkan secara maksimal. Oleh karena itu, dijelaskan A6 dalam pelayanan wisata Islami yaitu : Ability, Attitude, Appearance, Attention, Action dan Accountability.

Untuk mencapai optimalisasi A6 tersebut, maka diperlukan standa-standar kerja serta prosedurprosedur baku dalam melakukan pelayanan wisata Islami. Sedangkan dalam konteks yang lebih luas, maka diperlukan integrasi dari berbagai pelaku wisata, sehingga para wisatawan mendapatkan pengalaman yang menyenangkan dan memuaskan selama berada di Kota Padang.

Kegiatan Pelatihan dilaksanakan dengan baik dan lancar. Para peserta juga mengikuti dengan sangat antusias berbagai rangkaian materi yang diberikan. Hal ini dibuktikan dengan waktu masing- 
masing pemateri yang lebih panjang daripada rencana, dikarenakan banyaknya tanggapan dan pertanyaan dari para peserta. Oleh karena itu, acara yang pada awalnya direncanakan untuk ditutup pada jam 15.00 WIB, pada akhirnya ditutup pada jam 16.30 WIB

\section{Simpulan dan Saran}

Adapun simpulan yang di dapat dari kegiatan ini antara lain: 1) Pengetahuan dan keterampialn para pelaku wisata terhadap wisata Islami meningkat, 2) Para peserta mengaku bahwa kegiatan ini sangat bermanfaat, terutama dalam hal peningkatan omzet, kualitas dan kuantitas produk pariwisata, 3) Berdasarkan diskusi diketahui bahwa nomenklatur yang tepat dari pariwisata yang mengandung nilainilai Islami adalah wisata Halal bukan wisata Islami.

Berdasarkan simpulan di atas adapun sran yang dapat disampaikan yaitu: 1) Tim kegiatan Pengabdian Kepada Masyarakat melanjutkan proses kegiatan sehingga dapat menghasilkan luaran yang telah dirumuskan sebelumnya, 2) Untuk meningkatkan keterampilan pelaku wisata, maka kegiatan ini dapat dilanjutkan dengan pelatihan-pelatihan berikutnya, dengan peserta yang sama

\section{Daftar Pustaka}

Basu Swastha Dh. dan Irawan, 2002, Manajemen Pemasaran Modern, Yogyakarta: Liberty.

Basu Swastha Dh., 2002, Azas-Azas Marketing, Yogyakarta: Liberty.

Fandy Tjiptono, 2008, Service Manajemen Mewujudkan Layanan Prima, Yogyakarta: Andi.

Hermawan Kertajaya dan Syakir Sula, 2006, Syariah Marketing, Bandung: Mizan Pustaka.

Keputusan Menteri Pariwisata \& Telekomunikasi No. KM 94/HK.103/MPPT-87.

Kotler, Philip dan Amstrong, 2001, Prinsip-prinsip Pemasaran, (terj) Jakarta: Erlangga.

Kotler, Philip dan Keller, Kevin Lane, 2009, Manajemen Pemasaran, (terj), Jilid 2, Jakarta: Erlangga.

Kotler, Philip, 1997, Manajemen Pemasaran, (terj), Jilid 2, Jakarta: PT Prehalindo.

Lovelock, Christopher, Jochen Wirtz and Jacky Mussry, 2011, Pemasaran Jasa, Manusia, Teknologi dan Strategi, Perspektif Indonesia, Jakarta: Penerbit Erlangga.

M. Abdul Mannan, 2010, Teori dan Praktek Ekonomi Islam, Jakarta: Kencana.

Muhamad Muflih, 2006, Perilaku Konsumen dalam Perspektif Ilmu Ekonomi Islam, Jakarta: PT Raja Grafindo.

Rambat Lupiyoadi dan A. Hamdani, 2008, Manajemen Pemasaran Jasa, Jakarta: Salemba Empat.

Widyarini, 2012, Manajemen Pemasaran, Yogyakarta: Fakultas Syariah dan Hukum Press.

Yasid, 2001, Pemasaran Jasa, Konsep dan Aplikasi, Yogyakarta: Ekonisia.

Zeithaml, Valerie A and Bitner, Marry Jo, 1996, Service Marketing, International Edition, McGraw-Hill. 